\title{
LA MÚSICA EN EL CINE MUDO
}

Aurelio de los Reyes

\begin{abstract}
El día, figúrense ustedes, en que se pueda unir el cinematógrafo al fonógrafo... los muertos resucitan, pueden ser evocados como en las sesiones espiritas, pueden ser llamados de la eternidad para obligarlos a hablar, a moverse, a volver a la vida, ellos que tan cómodos deben encontrarse en el pais de los espectros Cada hijo de vecino puede tener a sus muertos queridos grabados en una película fotográfica sistema Lumière, y de alli lanzarlos por medio de la linterna mágica a la blanca pantalla para verlos animarse, al propio tiempo que el fonógrafo habla con la misma voz de aquellos que fueron.

Aquel que haya tenido una suegra brava no dejará de consolarse haciéndola bailar un bolero y hundiéndola después en las tinieblas, como la fatalidad hunde en el abismo a aquel a quien señala con el dedo.
\end{abstract}

Enrique Chávarri, "Juvenal'

Vaya este artículo para despertar la curiosidad del interesado en la historia de la música mexicana del siglo $\mathrm{xx}$, pues más que conclusiones, expongo planteamientos y vierto información, recopilada paralelamente a la investigación que realizo sobre la historia del cine mudo, acerca de conjuntos musicales y melodías que acompañaron a las proyecciones cinematográficas. No obedece a una búsqueda sistemática. Espero sirva para sugerir la riqueza de un tema que busca su historiador.

Considero que quien se interese en el tema debe conocer, además de la historia del pais, los problemas de la composición musical $y$, por supuesto, la historia de la música mexicana, sea de la popular o de la culta, para valorar debidamente la importancia que el cine tuvo en su desarrollo, pues es bien sabido que las salas cinematográficas fueron tribuna de difusión y que las películas obligaron a los músicos a buscar la idea musical que la imagen pedía; unos recurrieron a la improvisación, otros realizaron experimentos audaces al mezclar música de compositores disímbolos y opuestos entre sí con música popu- 
lar, obligados por el ritmo cinematográfico basado en el cambio violento de secuencias; otros tomaron elementos de grandes obras musicales, esto es, improvisaron variaciones; pero cualquiera que fuera la solución dada, durante la proyección cinematográfica se ponía a prueba su talento y su sensibilidad. El poder de abstracción de la imagen hacía que el público, en términos generales, no fijara su atención en lo que escuchaba; pocos eran los que abrían los oídos a la música por sí misma, quizá sólo cuando sabían que habría buenos intérpretes. Está por valorarse el papel que el cine mudo desempeñó en la historia de la música.

La aparición del cine fue la culminación del deseo ancestral del hombre de reproducir, crear o recrear un mundo a imagen y semejanza del mundo en que vive y del que forma parte. Con el cine las inquietudes renacentistas de reproducir un fragmento de la naturaleza en un cuadro estaban resueltas, lo mismo que resueltos estaban los problemas de la perspectiva y del movimiento. Hubo, sin embargo, por lo menos dos problemas que quedaron pendientes: el color y el sonido. Si bien los hermanos Lumière, creadores del cinematógrafo, experimentaron el color en una fecha tan temprana como 1896, al año de haber tomado y exhibido públicamente sus primeras películas, mediante la iluminación a mano de cada fotograma, con colores hechos, al parecer, de anilina, sus experimentos fueron desafortunados, como lo fueron los de sus sucesores hasta la década de los treinta, en que se encontró la manera de dar tonalidades más o menos reales y uniformes.

Por lo que se refiere al sonido, Edison acompañó sus películas para el kinetófono con trozos musicales y ruidos grabados en cilindros de cera ya en $1889 \mathrm{y}$, como es sabido, el cinematógrafo de los hermanos Lumière derivó su mecanismo de tal invento, pero los franceses no dieron importancia al sonido, que incluía la música. En años postexiores los experimentos de agregar sonido a las películas fueron tantos y de tan variadas maneras, que no nos referiremos a ellos porque los problemas de sincronización se resolvieron al finalizar la década de los veintes.

Hablaremos de la música viva, pues fue una constante que principió casi al mismo tiempo que la proyección de películas y dio lugar, con el tiempio, a soluciones originales.

La música fue acercándose paulatinamente a los cines hasta integrarse al espectáculo, convirtiéndose en un elemento casi indispensable y haciendo tradicionales al solista o al conjunto musical al pie de la 
pantalla que desaparecerían en la época sonora, no la música, que fue integrada al sonido para dar mayor efecto a la película.

En México desde los primeros años de cine hubo dos modalidades en la música que se tocaba en las salas cinematográficas, una, que se desarrolló primero, consistía en que una orquesta, un solista o un pequeño conjunto amenizaban las funciones al interpretar piezas musicales, breves, al principio y durante los intermedios de los programas; a veces se limitaban a una obertura, si el número de vistas (nombre dado a las películas) era corto, pero si eran doce o más (hubo ocasión en que proyectaron hasta cien títulos diferentes), el programa se dividía en dos, tres o cuatro tandas con un intermedio por lo general de diez a quince minutos para que el manipulador descansara (la proyección era manual), aprovechado por los músicos para deleitar a la concurrencia "con lo más escogido de su repertorio". La otra modalidad consistía en el acompañamiento musical de las películas, lo cual se hizo de diversas maneras, según lo veremos adelante.

Las primeras películas proyectadas en la ciudad de México asombraron a los cronistas por la "exactitud" con que reproducían la naturaleza, "se encuentra uno frente a un trozo de vida, clara y sincera, sin pose, sin artificios, sin fingimientos"; la película La llegada del tren era "tan natural, que hasta parece percibirse el sonido del tren y el murmullo de los pasajeros"; ${ }^{1}$ faltaba, sin embargo, "adunar el sonido al aparato... y dar color a las figuras; pero el movimiento de las escenas subyuga de tal manera que la imaginación todo lo suple". ${ }^{2}$

\section{Música para Carmen Romero Rubio de Diaz}

El primer proyecto de utilizar lá música en el cine del que tengo noticias fue con motivo de las celebraciones de las fiestas patrias de septiembre de 1896, justo al mes de efectuada la primera proyección. Se deseaba realizar sesiones cinematográficas en el circo-teatro Orrín de la plazuela de Villamil con "cincuenta de las mejores vistas"; se dijo que en los intermedios la Banda del Octavo Regimiento y la Orquesta Vega tocarían piezas musicales. ${ }^{3} \mathrm{Al}$ parecer fue la Banda de Caballería bajo la dirección de los maestros Payán y Santa Cruz la que

1 "El cinematógrafo Lumière", El Monitor Republicano, domingo 16 de agosto de 1896 , p. 3 .

2 Idem, El Universal, miércoles 19 de agosto de 1896, p. 3

3 "Las fiestas de septiembre", idem, martes 8 de septiembre de 1896, p. 2 
por primera vez tocó en una función de cine, según relata un periódico. ${ }^{4}$ El hecho tuvo lugar para hacer grata la visita a la sala de doña Carmen Romero Rubio de Díaz, esposa del presidente de la República, y de su séquito. La orquesta tocó "las más escogidas piezas de su repertorio". s

En los años 1897 y 1898, la utilización de la música en el cine fue una respuesta a la competencia, pues las películas nuevas eran pocas y tardaban en llegar; como el público se cansaba pronto de ver los mismos títulos, los empresarios se esforzaron por ofrecer otros atractivos. Según parece, el empresario del cinematógrafo perfeccionado Edison de la calle de las Escalerillas 7, a espaldas de la catedral, fue quien contrató por vez primera una orquesta para amenizar regularmente el principio y los intermedios de sus funciones. ${ }^{6}$

Para no quedarse atrás, el dueño del cinematógrafo Lumière de las calles del Espíritu Santo número 4 contrató a la familia Tovar, "cuyo cuarteto, maestramente organizado, toca las mejores composiciones". 7 E1 propietario del salón de Plateros 4, el día de la inauguración, adornó el sitio con macetones, cortinas, banderas y contrató dos orquestas para que alternadamente tocaran melodias, una en el zaguán y la otra en el interior; ${ }^{8}$ la primera llamaria la atención de los transeúntes, quienes al escuchar las notas sin duda se detendrían para ver a qué se debía aquel escándalo.

Hasta hoy no se sabe con precisión cuáles composiciones eran las que se tocaban en los cines esos años, quizá fueran fragmentos de música clásica, valses, polkas, números de zarzuela, es decir, la música de moda. Una idea nos la proporciona un programa que afortunadamente localizamos de una exhibición de la empresa de Enrique Moulinié y familia en Nogales, Sonora.

1. Notables exhibiciones del cinematógrafo Lumière.

2. Pieza de concierto, al piano, el señor González Gómez.

3. Un ballo in masche, por el señor Vargas.

4. Gran Vals El éxtasis, por la señora Gil del Real.

5. Exhibición por el cinematógrafo.

6. Monúlogo de La Tempestad y Give me good by por el señor Vargas.

4 "Gacetilla", El Tiempo, diciembre 2 de 1896, p 3

5 Idem.

6 "El Cinematógrafo Fdison", La Voz de México, viernes 2 de julio de 1897, p. 3.

7 "Gacetilla", El Tiempo, domingo 29 de agosto de 1897, p. 3

8 "El Cinematógrafo", El Imparcial, sábado 27 de noxiembre de 1897, p. 1 
DOI: http://dx.doi.org/10.22201/iie.18703062e.1983.51.1175

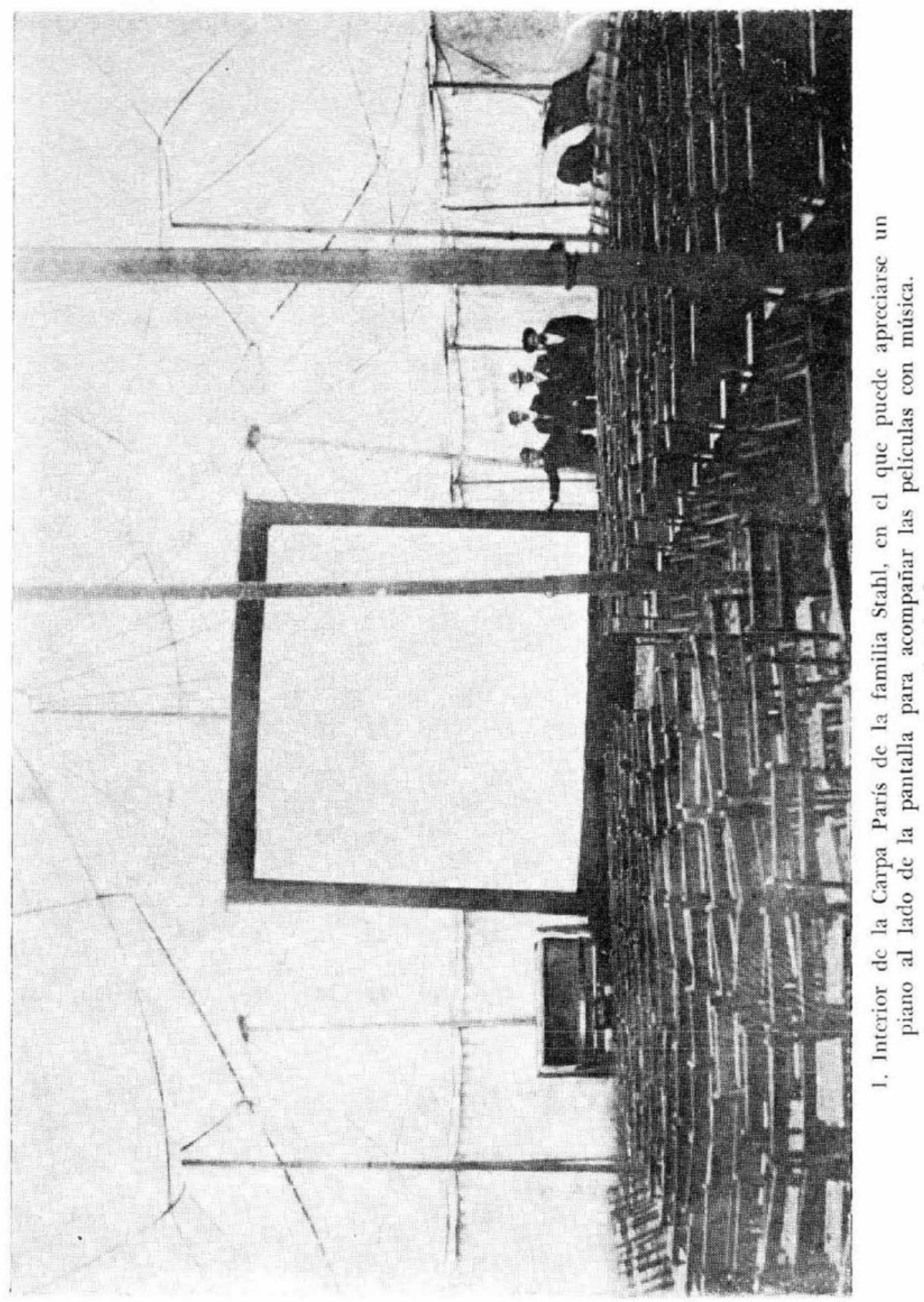




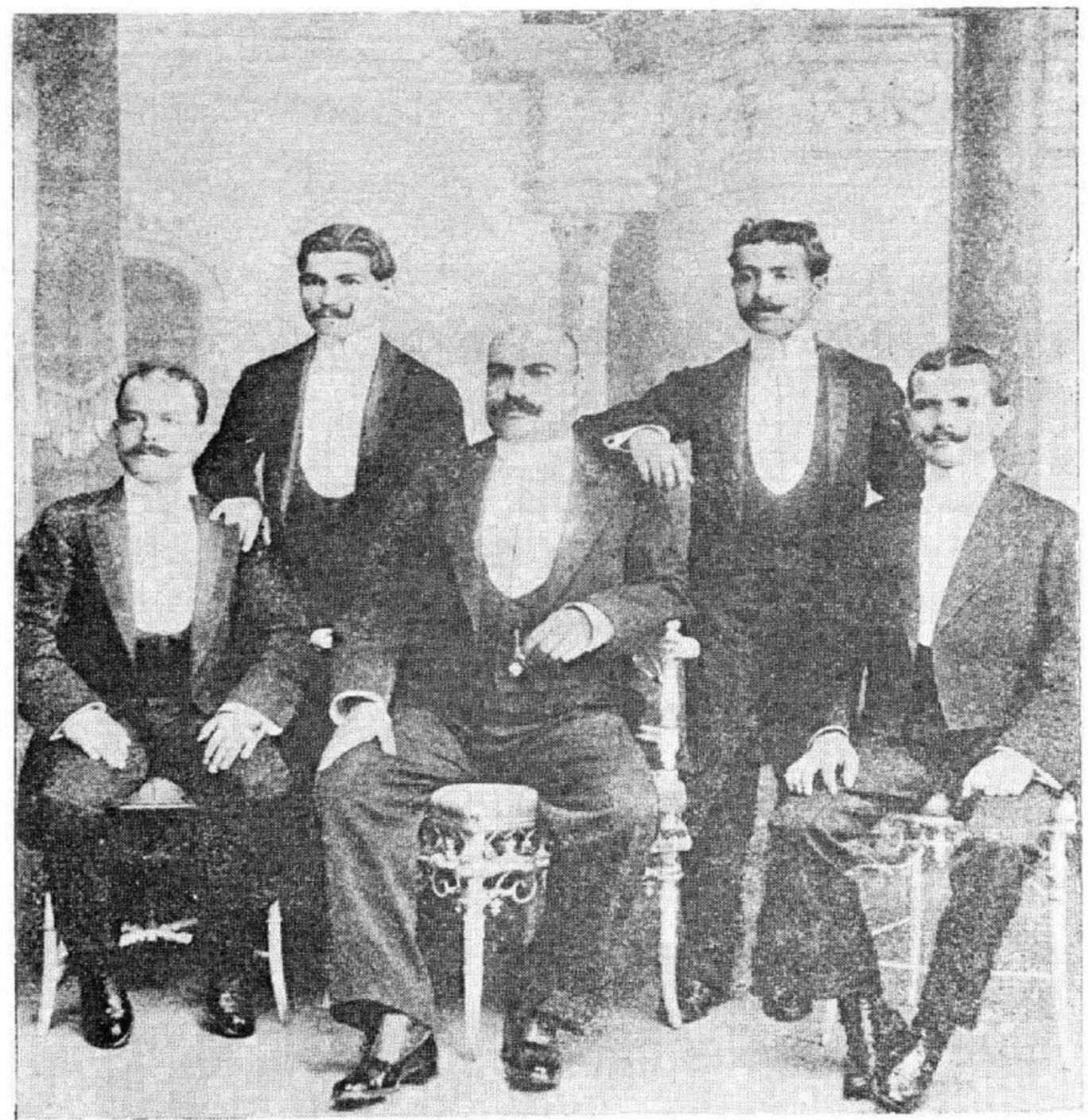

2. Quinteto Islas, cuyas interpretaciones musicales en los intermedios y al principio de los programas cinematográficos del teatro Riva Palacio, fueron muy populares el año 1905. 
DOI: http://dx.doi.org/10.22201/iie.18703062e.1983.51.1175

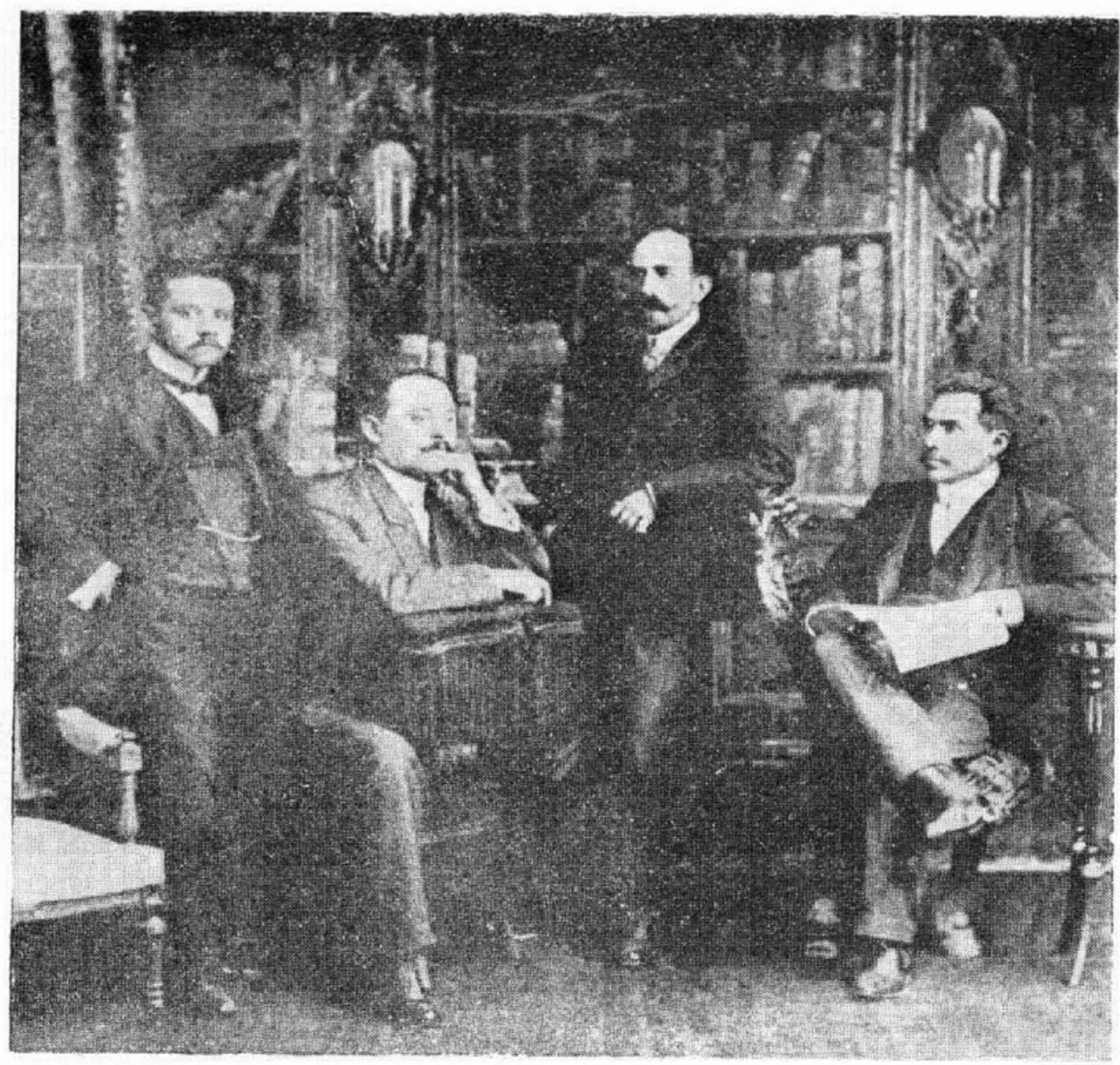

3. Cuarteto Saloma, afamada orquesta de címara cuyos conciertos se alternaron con exhibición de peliculas. 


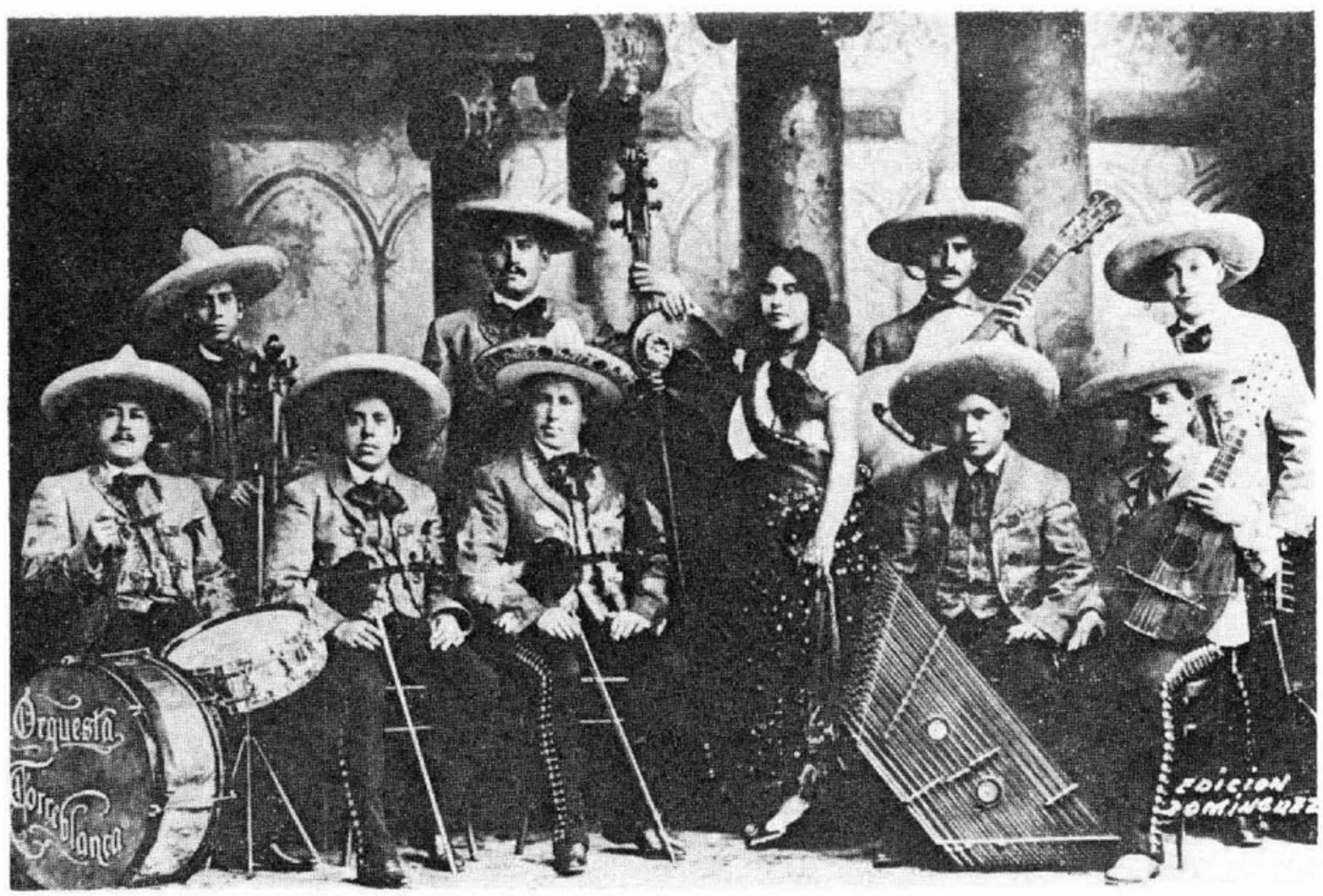

4.5. Fotografia y anuncio de la Orquesta Torreblanca, la que acompanaba las peliculas con música apropiacla.

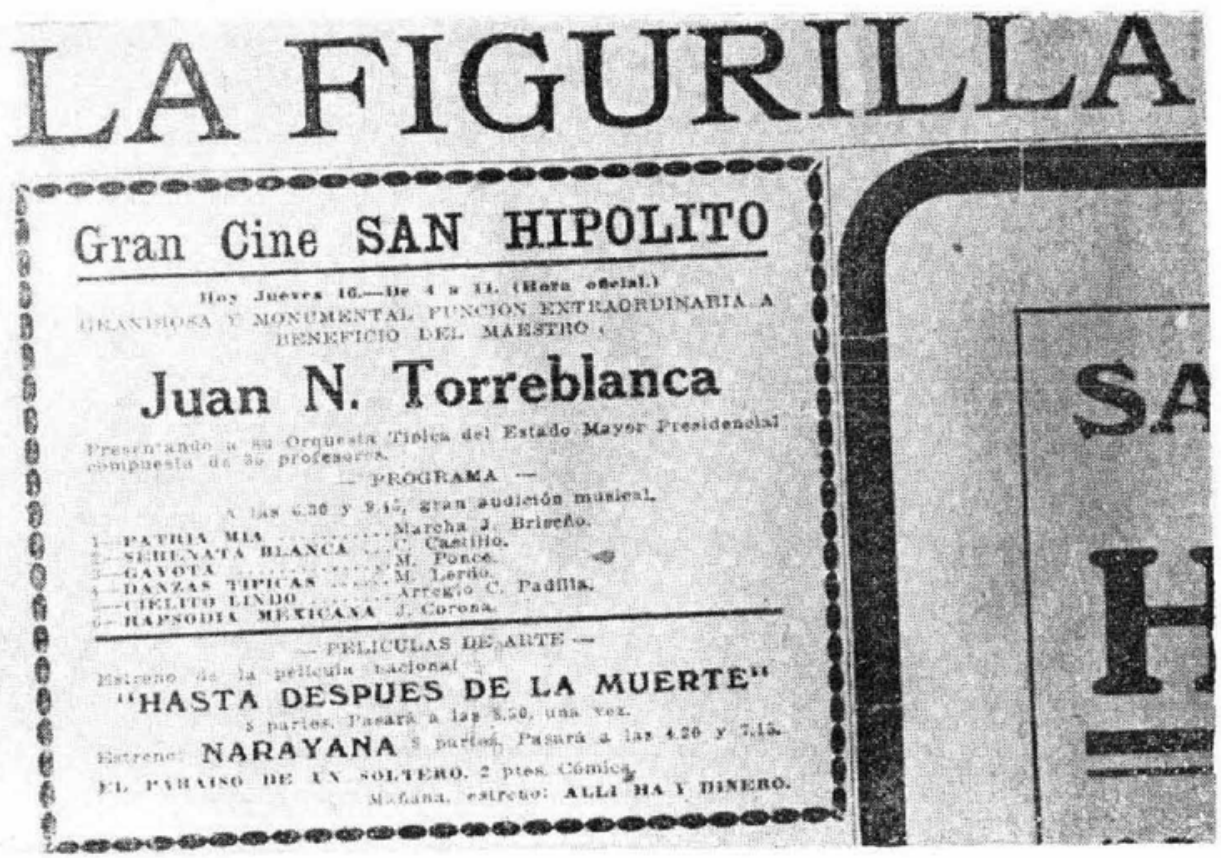


DOI: http://dx.doi.org/10.22201/iie.18703062e.1983.51.1175

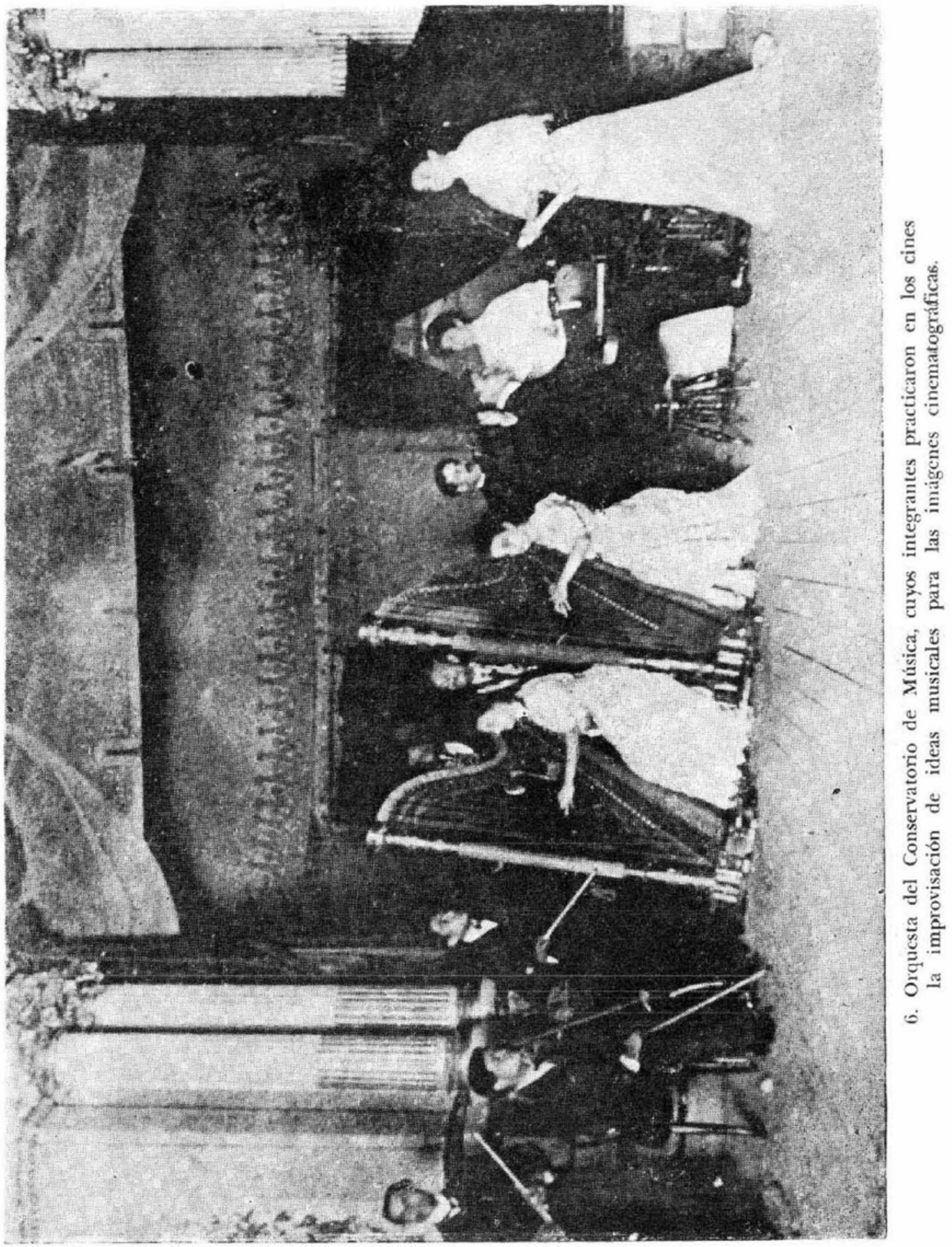




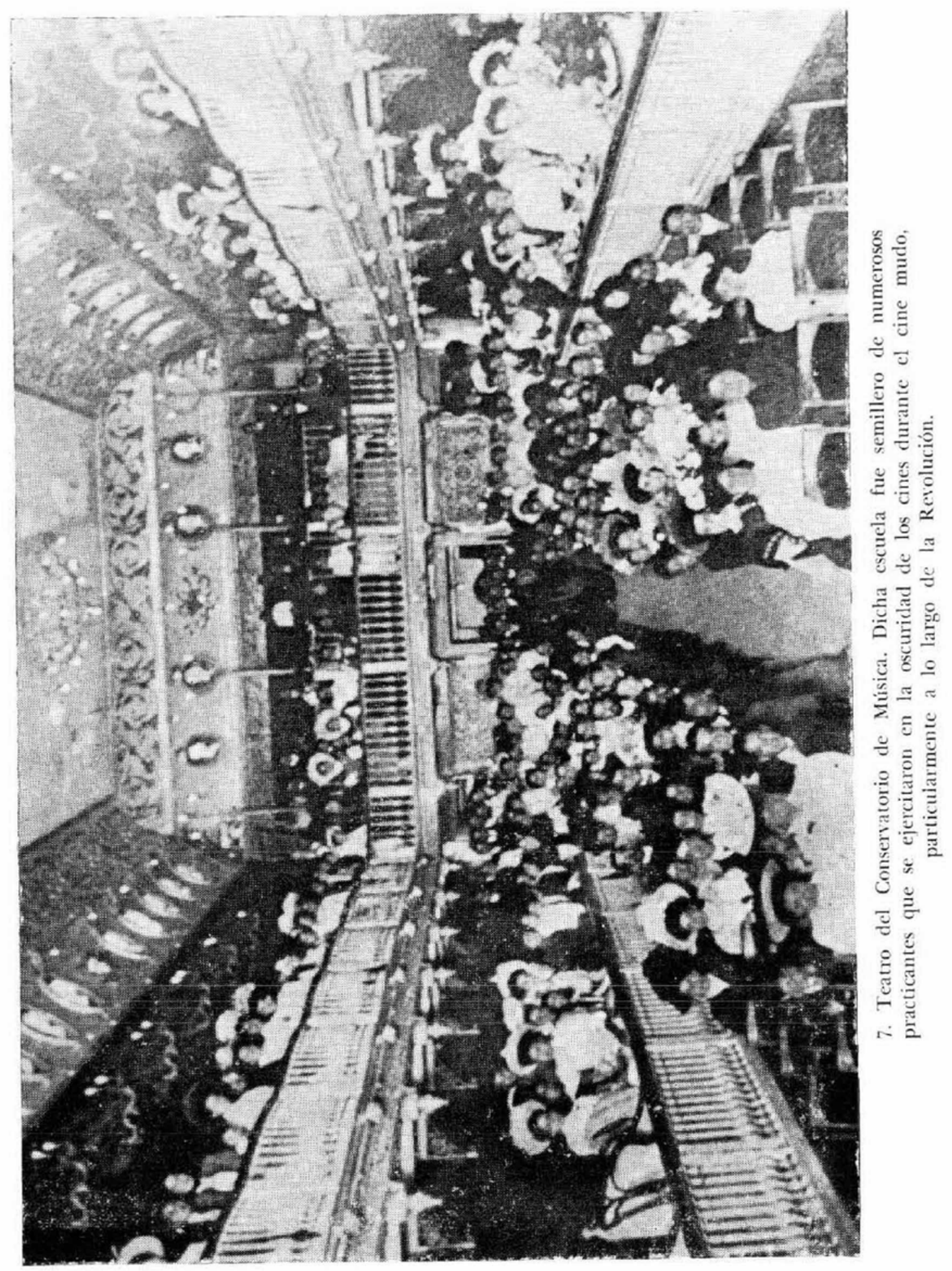


7. Romanza de Marta y rondó de Campanone por la señora Gil del Real. ${ }^{9}$

Como puede observarse, las películas ocupaban un segundo lugar; más bien cubrían los intermedios de un programa musical, quizá porque el repertorio de films del empresario era reducido. De cualquier manera, el programa nos ilustra sobre los gustos de la época y la manera de combinar composiciones de distinta índole en un mismo programa.

La introducción de las variedades musicales combinadas con funciones cinematográficas en 1898 enriqueció los espectáculos capitalinos y permitió la participación de una mayor variedad de conjuntos musicales, duetos, tríos, cuartetos, quintetos, bandas, típicas y solistas de piano, guitarra y violín.

Las variedades musicales al parecer comenzaron con un buen nivel de ejecución, que pronto decayó porque se abrieron veintitantos locales en corto tiempo, y al parecer, los ejecutantes calificados fueron insuficientes para satisfacer la demanda. Se improvisaron artistas y músicos y su calidad dejó mucho que desear. Por lo general el espectáculo consistió en bailables españoles, pasodobles, peteneras; o mexicanos, jarabes, sones; números de zarzuelas, españolas y mexicanas del género chico, y piezas musicales cortas, que tanto gustaban al público de aquellos años de 1898,1899 y 1900 . La mala calidad del espectáculo y la escasa o nula vigilancia de la policía, incapaz de atender tan inesperado número de locales, dieron por resultado que estallaran escándalos, que terminaban en violencia, lo que motivó el cierre de los locales. Los esporádicos salones abiertos o las temporadas de cine en los teatros de la capital hasta antes de 1906, no ofrecieron ninguna novedad digna de tomarse en cuenta, musicalmente hablando. Conjuntos pequeños o solistas alternaban de cuando en cuando con la exhibición de películas, como la niña María Aspíroz, que admiraba "por su precoz maestría en el manejo del violín" en el Palacio Encantado de Enrique Moulinié. ${ }^{10}$

\section{La provincia y la trashumancia}

Dejemos la capital del país y centremos nuestra atención en la ciudad de Orizaba y en un empresario ambulante, Carlos Mongrand, durante

9 Diario del Hogar, viemes 6 de mayo de 1898 , pp. 2 y 3

10 "El Palacio Encantado", El Entrencto, jueves 5 de diciembie de 1901, p 1 
los años de 1900 a 1906, cuando el cine se caracterizó por su trashumancia y sus temporadas efímeras en las ciudades del interior del país.

En Orizaba, un conjunto hizo el intento de adecuar la música al argumento y al ritmo de las películas; quizá la ciudad contaba con un centro de estudios musicales de cierta importancia, pues no fue una sola vez y un solo conjunto los que experimentaron en tal sentido " 11

A principios de 1901 llegó al teatro Llave la empresa Asecencio con su espectáculo cinematográfico combinado con un gramófono, "aparato reformado del fonógrafo que deleita a los espectadores con piezas de canto y concierto que se oyen perfectamente"; como novedad contrató al cuarteto del maestro Rómulo para "cubrir los intermedios y tocar a la hora de las vistas, lo que completa la ilusión del espectáculo". ${ }^{12}$ No sabemos qué música tơcó, si popular o clásica, o si improvisó melodías o si eran composiciones tradicionales escogidas adecuadamente para cada película, o si se limitó a tocar "lo mejor de su repertorio", haciendo caso omiso del argumento, esto es, valses, marchas, habaneras, polkas, mazurkas, romanzas, rondós o trozos de música clásica. La experiencia debió ser positiva, pues meses después otro empresario contrató al cuarteto Oropeza para acompañar con "majestuosos números de música religiosa" la exhibición de vistas estereoscópicas que representaban "los principales pasajes de la Pasión del Redentor". ${ }^{13}$ En otro pequeño salón abierto tiempo después, las películas fueron acompañadas por "los deseados actos de concierto de los filarmónicos chiapanecos que de continuo arrancan agradables y clásicas piezas a su sonoro marimbón". ${ }^{14} \mathrm{La}$ empresa Aguilar y Román J. Barreiro en una de sus visitas organizó un quinteto filarmónico, bajo la dirección del maestro Arnulfo Blanco, para que tocara durante las funciones cinematográficas, ${ }^{15}$ en la proyección de Fausto y La Condenación de Fausto (Pathé 1905) ejecutaron "la música especialmente arreglada a la vista por un reputado compositor parisiense". Sin duda se trataba de la música de Gounod.

\section{Marcha de honor para el general Diaz}

Por su parte, Carlos Mongrand, empresario francés que llegó a México en 1896i acompañado de su esposa, y que recorrió el centro, el norte y el

11 "Agencia teatral de Manuel Castro", Diario del Hogar, sábado 11 de abril de 1903, p. 3

12 "Cinematógrafo", El Cosmopolita, febrero 10 de 1901, p. 2

13 "Instantáneas artísticas", El Reproductor, abril 4 de 1901, p 1

14 Idem, El Cosmopolita, agosto 25 de 1901, p. 2.

15 "Noticias cortas locales", idem, mayo 27 de 1906, p. 3 
noroeste del país desde su llegada a México hasta 1906, en que se retiró del negocio, inició la utilización de la música en las películas en la ciudad de Guanajuato. El pretexto fue donar el producto de una función a los familiares del pintor Ramón Cárdenas, muy estimado en dicha ciudad, que falleció poco antes de una de sus visitas y que había dejado a su familia en penosa situación económica. Para llamar la atención, Mongrand contrató a la Banda de la Escuela Industrial, de la que formaban parte algunos alumnos del pintor; la función, además, la dedicó a los profesores y alumnos del Colegio del Estado, quienes, halagados en su vanidad, acudieron acompañados de familiares y amigos; ni duda cabe que su olfato comercial era muy agudo. Se dijo que la orquesta recibixía con su música a los concurrentes en la puerta del teatro Principal. ${ }^{16}$ La expectación despertada por la publicidad hizo que "desde muy temprano se agotaran todas las localidades, siendo necesario que el Regidor de teatros mandara a la taquilla que no se vendiera ya ni un solo boleto, pues todos los departamentos estaban llenos, enteramente llenos". ${ }^{17} \mathrm{Y}$ en efecto, la orquesta, bajo la dirección de Julián Espinosa, recibió en el póntico del teatro a los concurrentes; después, ya en la sala, tocó una obertura antes de la proyección de películas y, por último, acompañó, "con una marcha de honor" una vista en la que aparecía el presidente de la República paseando por el bosque de Chapultepec, "produciendo la inesperada marcha una tempestad de aplausos y vivas al señor general Díaz". ${ }^{18}$ El éxito fue tal, que el gobernador del Estado pidió al empresario permanecer en la ciudad durante las fiestas patrias de septiembre de 1902, para obsequiar a los guanajuatenses con funciones costeadas por el erario público. En Aguascalientes intentó perfeccionar la experiencia al hacer que la banda del Estado, dirigida por el capitán Payán, se colocara detrás de la pantalla para tocar "marchas adecuadas y toques de tambores" que resultaton de "grande efecto". ${ }^{19}$ Entre las "vistas musicalizadas" estuvo el reportaje cinematográfico sobre La visita de Monsieur Loubet, presidente de Francia, al zar de Rusia. Las dos orquestas seleccionaron piezas musicales que consideraron adecuadas al tema de las películas.

Durante cerca de dos años Mongrand no repitió el experimento, ni

16 "Agencia de contrataciones", Diario del Hogar, jueves 4 de septiembre de 1902, p. 3 .

17 Idem, martes 9 de septiembre de 1902, p. 3 .

18 Idem.

19 "Notas de la agencia de espectáculos de Luis A. Rivera", El Popular, 7 de enero de 1903, p. 2 . 
durante una exitosa temporada efectuada en la capital del país a mediados de 1903, para la que contrató una orquesta que, según los programas, sólo tocaba antes de la proyección de las películas y durante los intermedios. Quizá no es que el empresario no deseara continuar el experimento, sino que tal vez los músicos no se interesaban en colaborar de manera diferente a la costumbre ya establecida, quizá tenían temor de experimentar.

Hasta mayo de 1905 vuelve a hablarse de sus experimentos de acoplación musical al encontrar un conjunto que aceptó tocar expresamente para las películas; se trató de la Típica de Zacatecas dirigida por el maestro Antonio Martínez, "la cual orquesta es la que mejor se ha adaptado a esta clase de espectáculos por la propiedad y oportunidad de las piezas que elige para las diversas vistas"; 20 el éxito fue tal, que Mongrand agregó al conjunto musical a su empresa para que lo acompañara en sus viajes. En la última función de la temporada en el teatro Calderón y para hacer más emotiva su despedida, la orquesta tocó las ya populares Golondrinas. Después partieron para Morelia, donde la Típica ofreció la noche de su llegada una serenata en la plaza de armas, "siendo aplaudidas las diversas piezas que se ejecutaron"; ${ }^{21}$ y por supuesto que además de las serenatas, acompañó las películas con obras musicales cuya adecuación a la imagen gustó tanto al público que obligaba al empresario a "bisar" cada película; 22 la temporada fue "un triunfo ruidoso". De ahí se dirigieron a Monterrey para trabajar en el teatro Juárez y no obstante la separación de dos músicos, Agustín Salinas y Teodoro Reyes, la orquesta continuó "poniendo muy en alto el nombre de Zacatecas dondequiera que se presenta", 23 De Monterrey pasaron a Torreón y luego a Guadalajara; a su paso por Zacatecas y mientras el tren hacía un alto en la estación, el empresario y la orquesta descendieron al andén para tocar la marcha Zacatecas de Genaro Codina, para regocijo de los viajeros. ${ }^{24}$ En el teatro Degollado de la capital tapatía repitieron sus éxitos y la Típica mereció la felicitación del maestro

20 "El cinematógrafo en el Calderón", El Correo de Zacatecas, domingo 7 de mayo de 1905, p. 1 .

21 "La orquesta típica zacatecana en Morelia. El cinematógrafo Mongrand", idem, domingo 28 de mayo de 1905 , p 1.

22 "Siguen los tuiuntos de la orquesta típica de Morelia", idem, domingo 4 de junio de 1905 , p. 1.

23 "Gacetilla El cinematógrafo Mongrand", idem, domingo 16 de julio de 1905, p. 2.

24 "Gacetilla. El señor" don Carlos Mongrand", idem, domingo 6 de agosto de 1905, p. 2 
Augusto Azzali, renombrado músico italiano de aquellos años, según decir de la prensa. ${ }^{25}$ De Guadalajara fueron a Zamora y por último a Chihuahua, donde músicos y empresarios se separaron quién sabe por qué razones.

Vale la pena consignar que el empresario era tan popular en el país que durante una de sus visitas a Durango, el autor local Alberto Alvarado compuso la polka La mongranita en su honor. ${ }^{2} 8$

El empresario J. Saldivar, quizá enterado de los éxitos de Mongrand, en su visita a Zacatecas contrató la Típica de Fernando Ortiz para imitar los experimentos.

Jorge Sthal, que viajaba con una carpa con capacidad para dos mil espectadores, al llegar a las ciudades se informaba de los concertistas locales para contratarlos y combinar exhibiciones de películas con trozos de obras de música clásica, o de zarzuela, como ocurrió durante una de sus visitas a Tepic. En una función proyectó 21 películas de los más variados títulos en tres tandas; la primera la inició una obertura, la segunda "un capricho para clarinete con acompañamiento de piano por los señores profesores Ireneo Contreras y Pedro S. Andrade", y la tercera, el coro de los polichinelas de la zarzuela mexicana Chin-Chun-Chan que cantó un grupo de niños. ${ }^{27}$ Pero, por lo general, contrataba a un pianista local con su instrumento respectivo para amenizar las películas.

La costumbre de los empresarios ambulantes de utilizar concertistas locales atestigua la sólida educación musical captada con fidelidad en la novela del siglo pasado La mayoría de los autores coincide en señalar que era un elemento indispensable de lo que se consideraba una educación ilustrada, particularmente en las mujeres; quizá era una aportación del romanticismo; según Astucia de Luis G. Inclán y La bola de Emilio Rabasa las casas "decentes" de lugares apartados del país poseían su piano y recibían las partituras de los autores musicales europeos de moda; las novelas dejan traslucir la mecesidad de la música para desahogar o sublimar las pasiones amorosas, en Clemencia, de Altamirano una de las protagonistas.

Vistióse con esmero, y aún podría decirse que con coquetería. Sentóse al piano; pero cambiando a menudo papeles y no concluyendo ninguna pieza que comenzaba, más bien parecía agitada por una impa-

25 "Manuel Castro Agente teatral", Diario del Hogar, sábado 12 de agosto de $1905, \mathrm{p} .3$.

26 "Agencia teatral de Manuel Castro", idem, vietnes 6 de noviembre de 1903 , p. 3 . 27 "Chisporroteo cinematográfico", Lucifer, sábado 2 de junio de 1906, pp 1 y 2 " 
ciencia febril, que inspirada por el numen de la melodía. Jugaba con las teclas, improvisaba, mezclaba las armonías tristes de los maestros italianos con las notas profundas de la música alemana o con las alegres y ligeras de los maestros franceses. En fin, pensaba tocando y traducia en el piano sus pensamientos desordenados y confusos, y se volvía frecuentemente hacia la puerta, como si esperase la aparición que evocaba en lo íntimo de su alma. ${ }^{28}$

Otro uso de la música por los empresarios ambulantes consistió en contratar conjuntos locales para los convites, por lo general eran bandas que anunciaban por las calles las funciones cinematográficas acompañadas por muchachos "gritones"; aquéllas tocaban marchas y pasodobles y éstos invitaban con voz sonora a la gente a asistir a las proyecciones repartiendo programas y aventando cohetes de pólvora; cuando la orquesta dejaba de tocar, hacían sonar matracas y cencerros; el ruido debió ser fenomenal.

".. un soberbio ejemplar de artista en ciernes..."

El año 1906 es clave para el desarrollo de la exhibición cinematográfica por la apertura de distribuidoras de películas, que permitirán abrir numerosas salas en la capital del país y en las ciudades más importantes del interior. Los ambulantes cinematográficos por lo general se establecieron en un sitio, aunque no desaparecieron del todo. La competencia entre los dueños de los más de treinta salones abiertos en el transcurso del segundo semestre de ese año en la ciudad de México, hizo que recurrieran nuevamente a las variedades teatrales, pero ahora contratarian ejecutantes calificados; se esmerarian por ofrecer un espectáculo digno. Además de acompañar las películas con música, recurrirían a otros arbitrios: importar grandes órganos o improvisar orquestas con animales, tal como lo hicieron los empresarios del Teatro Apolo y del Salón Lumière de la segunda calle de Plateros 4 , respectivamente, éste, quién sabe qué trabajos tuvo que afrontar para integrar "una pequeña orquesta de gallos vivos y verdaderos, vestidos con elegante frac, chaleco y pantalones, que tocan violines, violoncellos, contrabajo y guitarra bajo la batuta de un hermoso gallo". ${ }^{29}$ En el vestíbulo del teatro Apolo se instaló un "orquestrión" japonés para que abriera el espectáculo cinematográfico y amenizara los intermedios. Dicho aparato era:

28 Ignacio Manuel Aitamirano, Clemencia, México, Porrúa, 1980, p. 28. 29 "Por los teatios", El Popular, martes 10 de julio de 1906, p. 1. 
una verdadera maravilla de música mecánica, única hasta hoy en la República. El original aparato, de un dibujo elegantísimo, está colocado sobre una plataforma o caja acústica, de unos cuatio metros de fachada por un metro de fondo y su ornato sube hasta el techo del vestíbulo. Ocupan el frente cinco manequías, que son un director de orquesta y cuatro ejecutantes; pero el efecto que produce el instrumento es el de una banda de setenta profesores con la más rica dotación de instrumentos de todas clases, inclusive sus bombos, platillos chinescos y todos los ruidos de una mumerosa banda. Por último, este gran aparato está exteriormente iluminado por una ofuscante profusión de luces eléctricas que le dan un aspecto deslumbrador y bello al mismo tiempo. ${ }^{30}$

Era movido por medio de electricidad y ejecutaba fragmentos de ópera y zarzuelas, fantasías, marchas, danzones cubanos y canciones populares mexicanas, entre otros ritmos. ${ }^{31}$ Cierta ocasión tacó el siguiente programa: Gran concierto, el guarani, danzón, El ferrocarril Central, polka; Fra Diávolo, Florodora, Viza Paris, Sobre las olas, La peseta enferma, El Gran Mogol y La Maritima, "produciendo dicho aparato el efecto de una gran banda con sus bien timbradas voces". ${ }^{32}$ Hacia 1911 parte del instrumento estaba en el vestíbulo del Salón Popular de la séptima calle de Capuchinas 119. Según el propietario, los instrumentos de latón estaban fuera de servicio y sólo se utilizaban "los que imitan una orquesta de cuerdas". Varios vecinos se quejaron de la constante repetición de melodías y del ruido, pues comenzaba a funcionar desde la mañana hasta avanzadas horas de la noche. Por orden del Ayuntamiento, el empresario Luis T. Maurente, lo sustituyó por otro menos ruidoso; ${ }^{33}$ no sabemos qué fue de él posteriormente.

En el salón Spectatorium, las películas eran acompañadas con música y canto, las composiciones que se interpretaban mientnas desfilaba por la pantalla "la dicha de dos amantes entre las flores, y las delicias de un idilio a la puesta del sol", eran canciones románticas, "die esas canciones llenas de pájaros y de flores". ${ }^{34}$ En otro cine, películas basadas en operas, Fausto, La condenación de Fausto, Aida, La Gioconda, El Barbero

30 "Inauguración del teatro Apolo", El Entreacto, jueves 21 de febrero de 1907, p. 4. 31 "Por los teatros", idem, jueves 7 de marzo de 1907, p. 3.

32 Idem, domingo 10 de marzo de 1907, p. 4 .

33 Archivo Histórico del Ayuntamiento, Gobierno del Distrito, Diversiones, leg. 4, exp. 252, fs. 4 .

34 "Por los teatros", El Popular, sábado 24 de noviembre de 1906, p. 2. 
de Sevilla, etcétera, fueron acompañadas con varias de las óperas respectivas interpretadas por conjuntos musicales y cantantes conocidos, ocasionalmente situados detrás de la pantalla. En el circo-teatro Orrín, "mientras en la pantaila se desarrollan escenas chuscas, la Banda de Policía ejecutó sus mejores piezas, siendo aplaudidísima, sobre todo La danza de las horas, la marcha de Preza y Lindas Mexicanas".

Quizá las orquestas típicas como la de Miguel Lerdo de Tejada y la de Torreblanca, pero sobre todo los conjuntos de cámara y los estudiantes del Conservatorio Nacional de Música, fueron los más favorecidos con la aceptación que tuvo el acompañamiento musical de las películas. Entre los conjuntos de cámara más populares estuvieron los cuartetos de Bruselas y Saloma, el sexteto Uranga y los quintetos Islas, Urresti y Reyes Palacios, pero solamente éste experimentó la improvisación de melodías acopladas al ritmo del film.

En las postrimerias del porfirismo destacaron dos egresados del Conservatorio: el joven de quinice años José Manuel Santiesteban que tocaba en el Salón Majestic, y Jesús Martínez, contratado por Jacobo Granat para tocar el piano en su Salón Rojo. Del primero se dijo que "en el Salón Majestic se exhibe de manera no tan sólo modesta sino inconsciente, un soberbio ejemplar de artista en cierne, un jovencito... que sentado al piano llega tan arriba, crece de tal manera, que el gran salón le resulta bajo y estrecho". ${ }^{3 a} \mathrm{E}$ l segundo adquirió prestigio por "improvisar en el piano la música al asunto representado"; ${ }^{36}$ durante la proyección de La guerra de Melilla, documental sobre la pacificación del Marruecos español, ejecutó "trozos de música patriótica española, con lo cual aumentó el entusiasmo del público, que aplaudió entusiasta". ${ }^{37}$ En el salón La Arcada, la orquesta del Conservatorio ejecutaba diferentes composiciones diariamente, "recibiéndose las piezas que se tocan de los centros musicales de Furopa y de Estados Uniclos". ${ }^{38}$ Se dijo que algunos cines brindaban al público algo más sustancioso que el telón de vistas y variedades de escenario, al convertirse "en el estímulo de la buena música en pianos, cuartetos y quintetos, que suelen resultar inreprochables, a pesar de la modestia típica de sus ejecutantes". ${ }^{39}$

$3 \tilde{3}$ "Cinematógrafos", El Entreacto, domingo 12 de abril de 1908, pp 1 y? 36 "Correo de teatros", El Imparcial, domingo 18 de julio de 1909 , p. 6 37 Idem, martes 19 de octubre de $1909, \mathrm{p} 8$. 38 "Anuncio", El Diario, enero 25 de 1908, p. 3.

39 "Cinematógrafos", El Entreacto, domingo 12 de abril de 1908, pp 1 y 2 


\section{La Revolución}

Durante la Revolución hubo cambios importantes ocasionados no tanto por la situación del país, cuanto por la adopción de la moda europea de escribir partituras perfectamente metronomizadas a las imágenes cinematográficas, debido a la conciencia que se adquirió de la importancia de la música en la proyección de películas. Destaca la participación de la orquesta de cámara Saloma, de diversas bandas militares, algunas de ellas patrocinadas por distintos generales revolucionarios, y de solistas egresados del Conservatorio Nacional de Música. Sobresale también la creación por compositores mexicanos de obras para películas italianas de tema histórico.

"...Yo no sé qué influencia tiene la música..."

El acompañamiento musical de las películas ininterrumpidamente durante los últimos cinco años del porfirismo en cualquiera de sus modalidades, había creado la conciencia de su necesidad, al igual que en otras partes del mundo. Según el teórico húngaro Bela Balázs, la música subrayaba las imágenes, las enriquecía, les daba profundidad y relieve, fuera cual fuera la clase de música que se tocaba. Formaba parte "del mecanismo... como la luz y la sombra". 40 Apenas se suspendia, las imágenes enmudecian cobraban el aspecto de sombras lisas y chatas, "se comprobó que la mayor parte del público ni siquiera advertía que en el cine escuchaba música; sólo percibían su existencia cuando faltaba". ${ }^{4}$ Y en efecto, un periodista comentó que en México,

yo no sé qué influencia tiene la música en el cine. Cuando la orquesta, el quirteto o el piano callan, el público se impacienta y no puede comprender que existe cinta cinematográfica sin acompañamiento de melodía. El caso es muy curioso y se nota que, en donde tocan los mejores axtistas, es donde acude más público, y es porque se aduna maravillosamente la sensación emotiva del momento álgido del tema desarrollado, a la melancolía suave y cadenciosa de un vals de Berger. ${ }^{42}$

Otro más atestiguó que

el silencio que se notó en la sala, cuando los filarmónicos, por des-

40 Bela Balázs, El Film, Losange, Buenos Aires, 1957, p. 261.

41 Idem.

42 "Por la pantalla", El Universal, marzo 17 de 1917, p 6 . 
cansar, dejaron de amenizar el espectáculo con sus agradables sones, fueron notas desagradables que causaron el descontento de la concurrencia, pero sabemos que la empresa, percatada de esas deficiencias, pondrá los medios para corregirlas, a fin de que las funciones dejen plenamente complacidos a los numerosos asistentes. ${ }^{43}$

".. Dad olvido a las amarguras del pasado"

Las migraciones de la gente del interior a la capital del país en busca de refugio, la entrada a ella de numerosos contingentes de revolucionarios de las diversas facciones en pugna, el hambre, la inestabilidad politica y el temor al presente $y$ al porvenir empujaron a la casi totalidad de los capitalinos al "averno cinematográfico". Está comprobado que el cine lejos de sufrir mengua con la revolución, alcanzó un desarrollo notable, en especial en el campo de la exhibición, particularmente durante los años críticos de 1914, 1915 y 1916. La gente buscaba olvidar su miseria diaria, se fugaba de la incertidumbre y los empresarios explotaban sus temores,

¿Mexicanos! Dad olvido a las amarguras del pasado. Uníos todos, porque la unión hace la fuerza ... en el Salón Rojo no hay peligro de que entre el más temible enemigo... Federales, voluntarios, revolucionarios, paisanos, pobres y ricos, tienen las mismas garantias en este hermoso salón de arte y recreo. ${ }^{44}$

La música de las películas contribuía a transportar al espectador aún más fuera de su realidad,

con los acordes de nuestra música y canto olvidaréis, con lo bien tramado de los argumentos de las grandes películas de arte, ... las penalidades de la cotidiana lucha y os quedará el grato recuerdo cle aquellas agradables horas de distracción culta y honesta que habréis pasado.

La música, incluso, excitaba el nacionalismo,

Las ovaciones se sucedieron haciéndose más intensas al oirse los vibrantes acordes de la Marsellesa, el canto patrio de Francia que

43 "Primeras exhibiciones de la película In hoc signo vincis", El Diario, domingo 21 de diciembre de 1913, $p_{n} 6$.

44 Luis Reyes de la Maza, Salón Rojo, UNAM, México, 1968, p. 123.

45 Idem, p. 151 . 
tiene, quizá el único de los extranjeros, el raro privilegio de conmover casi tanto como el nuestro propio. ${ }^{46}$

Durante los años críticos la músilca cinematográfica experimentó avances notables; la circunstancia, en especial el hambre, también empujó a los egresados del Conservatorio a aceptar cualquier trabajo, y como el negocio cinematográfico estaba en su apogeo, los empresarios ofrecieron una relativa buena paga, y así, por los cines desfilaron compositores, cantantes y músicos que destacarían posteriormente en la música popular y culta mexicana, como Felipe Llera, Mario Talavera, Carlos Chávez; incluso tenemos conocimiento de que cierto organista y compositor fue pianista de cine, y según información recopilada, la experiencia cinematográfica fue básica para su ulterior desartollo, acorde con el hábito de improvisar en la iglesia. Se dice que los egresados del Conservatorio o de las escuelas de música recorrían los cines donde sabían que tocaba un compañero para escuchar sus improvisaciones.

He aquí un programa típico de la Revolución, de la ocupación carrancista de la ciudad de México en 1914.

La banda militar del Primer Jefe don Venustiano Carranza dará un selecto concierto de 5 a 9 p.m., tocando danzones cubanos y veracruzanos, y estrenando Lloraba el corazón y Julia. La orquesta Típica de diez profesores del C. Álvaro Obregón, ministro de la guerra, tocará de 4:30 a 9:30 p.m., hermosos danzones, bajo la dirección del maestro Federico Rolán. Felipe Llera y señora y los demás artistas del Sexteto del Salón Rojo deleitarán a nuestro público con selectos trozos de ópera y canciones populares. ${ }^{47}$

Es de creerse que el acompañamiento musical de las películas en la mayoría de los cines era cosa común, tan común que los anuncios periodísticos omiten cualquier referencia a los ejecutantes. Las crónicas que de cuando en cuando se publican sobre las funciones en salones populares hacen referencia a ella, a pesar de que los anuncios de las salas no la mencionan,

sea o no nuestro deseo, en venideros días no tendremos más que conformarnos con el único espectáculo que nos reste: las películas de quinientos, mil, dos mil o más metros, al compás de una empa-

46 Idem, p. 118.

47 Idem, p. 151 . 
lagosa musiquilla de piano, en que Chopin anda de bracero con Abundio Martínez, y en que la señora Chaminade se da de cachetes con nuestro excelente Miguel Lendo de Tejada. ${ }^{48}$

Cualquier intermitencia de luz, cualquier tropiezo del manipulador, cualquiera incomplacencia de la orquesta, suscitan en el acto una rechifla, una grita de mil demonios, grocera, imbécil, una sambra de salvajes quebrantadora de los nervios. ${ }^{49}$

\section{La pelicula concierto}

El Salón Rojo sobresalió por convertir la música en un atractivo tan poderoso como las películas mismas. El empresario Jacobo Granat, por sus nexos comerciales con productores cinematográficos europeos, estaba bien informado de los adelantos y trataba de aplicarlos en México; de vez en cuando otro empresario se le adelantaba en imponer alguna innovación.

Entre las innovaciones puestas en práctica está lo que se llamó película-concierto, consistente en acompañar la proyección de films con trozos de ópera o fragmentos de sinfonías corales, para el lucimiento de músicos y cantantes.

El film d'art de Pathé, protagonizado por actores de la Comedia Francesa, despertó el snobismo de la sociedad y de la crítica, a partir del inicio de su proyección en México hacia 1909. En la prensa aparecieron esporádicos comentarios que alababan sus excelencias y menospreciaban la calidad de otro tipo de películas; un sector de la sociedad lo consideró una expresión de lo chic. El film d'art preparó el terreno para innovaciones musicales más sofisticadas introducidas por è film hịstóntico italiano. Se puede decir que Marco Antonio y Cleopatra (1912) de Guazzoni inició en México la modalidad de las películasconcierto. Se dijo que su proyección en el Salón Rojo fue realzada por "una magnifica orquesta hábilmente dirigida por el maestro Alberto Amaya e integrada por profesores del Conservatorio". ${ }^{50}$ Continuaron In hoc signo vincis y El milagro de la virgen, "leyenda interesantísima que se proyecta con el complemento de su hermosísima música, ejecutada por veinte profesores y con la cooperación de los artistas de este salón

48 Carlos González Peña, "La decadencia del teatro", El Mundo Ilustrado, domingo 17 de noviembre de 1912 , p. s n.

49 "El Sherlockhomismo cinematográfico", El Pueblo, sábado 23 de septiembre de 1916 , p. 3.

so "Anuncio", La llustración Semanal, diciembre 2 de 1913, p. s. n 
a cuyo cargo está la parte vocal". 51 Para Espartaco un autor compuso una obra musical expresamente. ${ }^{52}$ Para El Paraiso Perdido, basada en la obra de Milton, hubo "música especial a gran orquesta"; 53 lo mismo que para Los cien días o la caida de Napoleón. Durante la exhibición de la cuarta parte de Muero.. pero mi amor no muere, con Lyda Borelli, "una notable soprano lírica" cantó el Ave Maria de Gounod. 54

En 1915 la película-conciento era un fenómeno cotidiano en varios cines de la ciudad de México. En uno de tantos anuncios leemos, "debut del famoso tenor señor Mario Talavera, que cantará en unión de la notable soprano señorita María Gallardo que tanto fue aplaudida el día de su debut el domingo pasado, señoritas Abunza e Islas, señoras Hernández y Corral, acompañadas por la agrupación artística Saloma". 55 En otro, "tomarán parte en esta selecta función los más famosos cantantes de México, acompañados por la agrupación artística Saloma, quienes ejecutarán deliciosos trozos de ópera". Un tercer anuncio, "el gran concierto vocal e instrumental que amenizará esta espléndida función está encomendado a distinguidos cantantes de la capital, acompañados por la orquesta del Conservatorio". 56 Transcribimos un último anuncio que programaba el debut de Ana María Martínez.

alumna del Conservatorio Nacional de Música, que dotada de una exquisita voz de mezzo-soprano será el encanto de su auditorio. El señor Ángel Ayala, excelente tenor de primera fuerza, también hará su début en esta función. La orquesta y artistas del Salón Rojo, cuyo selecto repertorio es inagotable, ejecutarán las mejores obras musicales que más agradan al distinguido concurrente. ${ }^{57}$

La película-concierto era cosa gastada y vieja en 1916, cuando llegó a México la célebre Cabiria (1914) de Giovanni Pastrone.

Se dice que tal película fue una de las primeras en la historia del cine mundial para la que se compuso música especial para realzar algunas escenas, sin embargo, tal hecho fue consecuencia de experiencias anteriores. En efecto, hacia 1910 era frecuente que músicos italianos

б̆ "Anuncio del Salón Rojo", El Diario, martes 23 de diciembre de 1913, p. 5 . 52 Luis Reyes de la Maza, op, cit, $p_{\text {" Ill. }}$

$5 \mathbf{3}$ Idem.

54 "Anuncio del teatro Hidalgo", El Diario, abril 8 de 1914, p. 8

55 "Anuncio del Salón Rojo", La Prensa, febrero 14 de 1915, p. 5.

56 "Anuncio del teatro Garibaldi", $E l$ Monitor, jueves 8 de abril de 1915, p. 4.

57 "Anuncio del Salón Rojo", idem, domingo 11 de abril de 1915, p. 5 
escribieran partituras originales, "anunciadas e interpretadas durante la función". 58 En 1912 en Paris se había experimentado ya la película concierto con Quo Vadis?, para la que la compañía Gaumont, su distribuidora, "encargó una partitura especial al compositor Jean Nogués y presentó el film con el acompañamiento de un coro de 150 ejecutantes". ${ }^{99}$ La diferencia entre las experiencias anteriores a Cabiria consistia en que para ésta se escribió una sinfonía, La Sinfonía del fuego, para acoplärla a las "imágenes trágicas del incendio de Cartago y de la flota romana"; 60 mientras la orquesta y el coro interpretaban la melodía, las palabras del pontífice Kathalo fueron cantadas por un barítono; ${ }^{61}$ la música era acorde con la grandilocuencia de la narrativa de Pastrone. Otra novedad fue que la partitura se remitía a los distribuidores con la película.

Cabiria, al parecer, llegó a México sin su partitura, lo que no fue problema para que el maestro Romualdo de Parma compusiera una obra, que fue interpretada por una orquesta, de "escogidos profesores" del Conservatorio Nacional de Música, ${ }^{62}$

\section{La cine-melodia}

Se dice que David Wark Griffith se inspiró en Cabiria para realizar El nacimiento de una nación (1915) y que trabajó estrechamente en la elaboración de una partitura especial con el compositor Joseph Carl Bail, ${ }^{63}$ experiencia que repetiría en Intolerancia (1916). Después de Grifflith, en Estados Unidos fue práctica común vender la película con su partitura correspondiente. En México, se podía comprar el tema musical de las películas. En realidad, lo hecho por el cine norteamericano fue dar proyección universal a un experimento que en Italia era tradicional desde 1910

Lo mismo que Cabiria, El nacimiento de una nación e Intolerancia llegaron a México desprovistas de su música original porque fueron introducidas de contrabando. Creemos, no obstante, que no fue obstáculo para que los músicos locales les adecuaran o compusieran una melodía.

\footnotetext{
58 Pierre Leprohon, El cine italiano, Exa, México, 1971, p. 56.

59 Idem, p. 40 .

60 Idem, p. 56

61 Roberto Paolella, Historia del cine mudo, Eudeba, Buenos Aires, 1967, p. 165

62 Luis Reyes de la Maza, op, cit., p. 144.

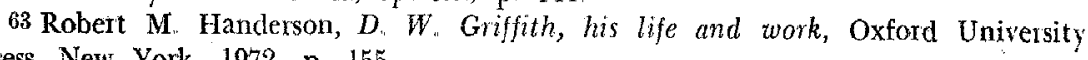
Press, New York, 1972, p. 155
} 
". Como pobre.. : me concreto a pasar al piano lo único que sé..."

Na todo lo que relumbra es oro. Así como unos músicos ejercitaban su habilidad en los cines, había otros, fracasados, que renegaban de su oficio porque su anhelo era tocar grandes conciertos. Sus sueños eran remotos, tan remotos como lo estaba la terminación del gran Teatro Nacional, meta de sus aspiraciones. Aceptaban tocar en el cine porque no sabían otro oficio, muy a su pesar, con disgusto, no les interesaba adecuar la música a la película; tocaban de mala gana y lo que les clictaba su voluntad. Rafael Pérez Taylor, que escribía en El Universal con el seudónimo de Hipólito Seijas, inició una visita a los cines poco frecuentados por periodistas, criticó el pésimo acompañamiento de la película con un sonsonete monótono que producía somnolencia ${ }^{64}$ y la mezcla de fox-trots y two steps con música de Chopin y Beethoven. Sus artículos produjeron la respuesta de los interpelados, que son documentos de inestimable valor para conocer su mísera situación. Uno replicó que no era extraña la mala calidad de su trabajo puesto que lo único que le interesaba era obtener el dinero indispensable para sostener a su familia.

cuando llegamos al cine fresquecitos, tocamos con gusto media hora, a veces una hora; pero surge el cansancio, la monotonía de tocar siempre lo mismo. Como pobre, no puedo comprar las últimas novedades y me concreto a pasar al piano lo único que sé, lo que he aprendido; doce two steps, ocho valses, unas cuantas mazurcas, unos arreglos de ópera, algo de opereta y se acabó. Nosotros no nos damos cuenta de la película. ¡Tenemos tan fatigada la vista! Y eso de estar encorvado, como un vencido, sobre el piano, sobre ese instrumento que fue mi ilusión, cuando iba al Conservatorio, pero que fracasado, lo tengo ahora como el pretexto para vivir. Y las horas brotan pavorosas para nosotros. Desde las cuatro de la tarde hasta las once de la noche jsiete horas continuas! A veces sí. He compuesto algunas danzas, pero cuando se me olvida alguna pieza y la película pide algo trágico, improviso repentinamente para luego olvidarme de lo que he improvisado. Esta labor agotante, que cansa y mata no tiene ya parentesco ninguno con el arte. Cuando al arte se le toma como mercancia y hay que vivir de él, jah, mi amigo!, el arte es implacable, vengativo, nos deja, nos abandona y ya sin inspiración ni ilusiones arrastramos nuestros pocos conocimientos por los cines a razón de tanto la hora.

64 "Por la pantalia", El Universal, marzo 27 de 1917, p. 7. 
La imagen que del pianista describió Pérez Taylor causa tristeza y lástima.

con su cubeta desorientada y llena de grasa; con la pelambre hirsuta que le caía en salutación por las sienes; con su principio de corbata, que fue anuncio de sedería y con sus ojos borrosos y llenos de amarga tristeza, dejaba caer sus manos huesudas sobre los panecillos de confección chinesca y con gran nerviosidad los llevaba a sus labios para morderlos en declaración absoluta del apetito no desmentido.

Para colmo, los pianistas enfermaban con frecuencia de los riñones lo que aumentaba sus gastos; no disfrutaban de ninguna protección social, "¿Y todo para qué? para llevar unos cuantos centavos a la casa a costa de nuestra vida, que vamos dejando en jïrones sobre el taburete del odiado piano". ${ }^{65}$

Otro pianista habló, además del comportamiento del público. A veces tocaba con gusto, improvisaba, acoplaba la melodía a la película, se abstraía con su trabajo, entraba en extasis de "gozo artístico y espiritual",

cada momento más deleitoso ... cada momento más artista... hasta que un ruido infernal, ensordecedor [lo sacaba de su abstracción, era el público que] daba con los pies sobre el pavimento [de madera], locamente, furiosamente, bárbaramente, porque el cuadro luminoso de la pantalla está desviado ... El pianista no ha implorado ni implora un apllauso, que satisfecho quedaría con creces, con un poco de silencio en su auditorio. Desilusionado y triste, cumple sus seis horas de martirio haciendo gimnasia de dedos, tocando, si no completamente con "ruido", el desarrollo de la película que, sin ruido, no está completa.. 66

La explotación de los músicos hacía necesaria su sindicalización. Bajo el gobierno de los sonorenses, iniciado por Adolfo de la Huerta en junio de 1920 llegaría una época propicia para llevarla a cabo, se agruparian en la Unión de Filarmónicos, y se afiliarian a la Confederación de Sindicatos del Distrito Federal, la que, a su vez, pertenecía a la CROM de Luis Napoleón Morones. Curiosamente, los músicos no se afiliarían a la Unión de Empleados Confederados de Cinematógrafo

65 Idem, mayo 5 de 1917, p. 10.

66 Idem, mayo 12 de 1917, p. 10. 
que agruparia a los proyeccionistas, boleteros, empleados de puerta, mozos, veladores o guarda-casas y acarreadores de películas. A principios de los treinta estallarían una huelga en los cines para defender sus puestos que la sonoridad les quitaba. Todo fue inútil, puesto que el cine mudo, las películas-concierto y las cine-melodias eran cosa del pasado. El proceso era irreversible.

\section{Música para las peliculas nacionales}

Por lo que se refiere a la producción mexicana de películas, no he encontrado noticias hasta el momento de que hubiera una composición musical específica para una película determinada. Se sabe, sí, que Triste Crepúsculo (1917) de Manuel de la Bandera, de tema costumbrista, fue acompañada con música mexicana en algunas funciones, ejecutada por alumnos del Conservatorio Nacional de Música; y que había sido interpretada por alumnos de la clase de mímica cinematográfica del propio Conservatorio; el hecho de que algunos de sus compañeros de la clase de composición tocaran durante esas proyecciones, fue una deferencia; no ejecutaron música compuesta expresamente para la película. Miguel Lerdo de Tejada adaptó la música para Alma de Sacrificio (1917) de Joaquín Coss. Se sabe también que durante algunas exhibiciones de El Escándalo (1920) de Alfredo B. Cuéllar, la Típica Lerdo, del mismo maestro Lerdo de Tejada y que tomaba parte en la cinta, interpretó música apropiada, de la que al parecer no se imprimió ninguna partitura, por último, parece que en las exhibiciones de En la hacienda (1921) de Ernesto Vollrath, se tocó la música de la zarzuela del mismo nombre de Federico Carlos Kegel en que se basaba su argumento.

De 1810 o Los Libertadores, es de la única cinta mexicana de que encontré noticias a la mano de que fue musicalizada conforme a la tradición de las películas-concierto. Cuenta Carlos Martínez de Arredondo, su productor,

quisimos hacer algo más que la presentación común, y se le adaptó a la pelicula una música especial, con la colaboración del maestro Fausto Pinelo, y en el foro preparamos lo necesario para imitar los ruidos. Al salir en la pantalla el reloj que marcaba las once de la noche, un murmullo de aprobación en la sala del teatro coincidió con las once campanadas que dejaron oirse. La venerable figura del Padre de la Patria, llamando al pueblo a luchar por su inde- 
pendencia, fue acogida con un grito de hondísima emoción: IViva el Cura el Hidalgo!, seguido de nutridos aplausos. Después, cuando Hidalgo, empuñando el estandarte de la Virgen de Guadalupe, atacó la Alhóndiga de Granaditas, los toques de clarín que ondenaban el asalto, el tronar de los cañones, el estallido de la fusilería, Hevaron al delirio el entusiasmo del público, que daba voces, enardecido, como si estuviera realmente en el campo de lucha. Al final, la orquesta tocó nuestro himno, acompañado por las dianas de cornetas y tambores, para saludar la bandera nacional que ondeó en la pantalla con sus vivos colores verde, blanco y rojo, iluminados a mano. Yo, allí junto a la caseta, experimentaba una de mis más grandes emociones. Todavía hoy, al recuerdo de aquella noche se humedecen mis cansados ojos. ${ }^{67}$

La producción argumental mexicana de 1917 a 1930, cuantitativamente hablando, fue de más a menos, y por lo mismo, las posibilidades de desarrollar composiciones cinematográficas fueron menores que en el movimiento musical en general. Al parecer los músicos de cine no siguieron las teorías nacionalistas de Manuel M. Ponce como lo hicieron otros compositores de teatro de revista y de carpas, cuyas obras recibieron gran impulso con la aparición de la radio en 1922. Que sepamos, no hubo cine-melodías nacionalistas, o si las hubo hasta el momento no las hemos detectado.

Los músicos de cine fueron condenados a desarrollar temas melódicos para película extranjera, sobre todo norteamericana y alemana y si crearon obras originales, se desconocen, puesto que sus esfuerzos terminaron con la llegada del cine sonoro y sufrieron los rigores del olvido. Ignoramos si obedecían a una composición tradicional o la película los obligó a hacer innovaciones, como ocurrió en Estados Unidos, pues allá se llegó a la originalidad, se dice que las modificaciones sufridas a principios de siglo por el ragtime tuvieron su origen precisamente en la oscuridad de los cines. A veces la originalidad consistía, como en México, en mezchar música culta con música popular o de compositores disimbolos y opuestos o de diferente nacionalidad; la característica común de la cine-melodia era su ritmo cinematográfico, Entre los popurris de música clásica utilizados por los norteamericanos se encuentra el de El general de Buster Keaton (1927) ; el de La marca del Zorro (1920) con Douglas Fairbanks, el de Sangre y arena (1922) con Rodolfo Valentino, el de

15. Gabriel Ramirez, El cine yucateco, México, UNAM, 1980, pp. 36, 37 
El ladrón de Bagdad (1924) en el que se mezclaba música de Rimsky Korzakov, Berlioz, Debussy y Borodin interpretada, para colmo, al modo de la música del medio oeste norteamericano para lograr una mayor ambientación y adecuación; o el de El pirata negro (1926) en que se combinó música de Lecuona, Falla, Albeniz con música popular mexicana. En Estados Unidos la música específicamente cinematográfica tendría continuidad en el cine sonoro.

En México no habría continuidad. La música para las películas sonoras serían adaptaciones de los éxitos teatrales o radiofónicos, a la que se incorporarían, además, la música de salón, tan popular en los veinte; tales géneros, sobre todo el del teatro de revista, encontraron un clima favorable para desenvolverse con desenfado esos años. Por lo mismo el trasplante de obras de teatro del género chico mexicano a películas: tal es el origen de la comedia ranchera; sus argumentistas, musicalizadores y la mayoria de los actores de comparsa procedían del teatro.

A cambio de una producción cinematográfica mexicana raquítica, nos encontramos con una variada y rica cantidad de obras musicales para salón y teatro, sea zarzuela española y mexicana, revista o variedades. Cabe subrayar que ambos tipos de música fueron estimulados por los cines, porque algunas salas alternaban películas con variedades musicales, otros organizaban en sus vestíbulos espaciosos del primer piso, concursos de fox-trot, two steps, danzón, tango, charleston, etcétera; la radio daría mayor difiusión a este tipo de música. No es extraño, por tanto, que en la primera película mexicana con sonido óptico exhibida con éxito, Santa (1931) de Antonio Moreno, se escucharan canciones de Agustín Lara, quien poseía una rica experiencia en ambos géneros musicales: había sido músico de prostíbulo y poseía su propia compañía de obras revisteriles que trabajaba con "ruidoso éxito" en el teatro Politeama.

El director musical de Santa fue Miguel Lerdo de Tejada, que desde finales de la primera década del siglo a menudo acompañaba con su Típica la proyección de películas y que adaptó música a dos cintas nacionales mudas, pero, curiosamente, en Santa le pesó más la tradición teatral y radiofónica que la cinematográfica: sólo en tres fragmentos, al principio, durante la presentación de los créditos, en las primeras escenas de ambientación, y al final de la película se escucha un fondo musical apropiado a las imágenes, como si equivalieran a una obertura y a un final de un programa de películas mudas: lo demás son números 
de teatro de variedades y radiofónicos intercalados. La primera secuencia en que escuchamos música de fondo es la de la feria: la cámara toma diversos panoramas en los que apreciamos juegos mecánicos, una rueda de la fortuna, un volantín o carrousel; poco a poco el interés se centra en la actriz principal, en Santa, que pasea la tragedia de su abandono y desvirgamiento mezclada con los concurrentes, mientras escuchamos las notas de una melodía norteamericana que, se supone, difunden los altoparlantes de los juegos mecánicos; termina, y se escucha música mexicana, la cámara se detiene y retrata, una típica semioculta que la toca ¿será acaso la Típica de Miguel Lerdo de Tejada? Lo que escuchamos y vemos después apoya nuestras conclusiones: música de piano en el prostíbulo; la canción tema nos remite a la radio más que al teatro o al propio cine, radio que no tarda en aparecer en un primer plano: Santa lo enciende para escuchar una canción cuya letra tiene una intención dentro del argumento, al terminar, lo apaga; restan dos trozos musicales, uno, de corte norteamericano bailado en el patio de una mansión por un coro de mujeres -quizá el coro de la compañía revisteril de Agustín Lara-, y un danzón dedicado a Santa.

Considero que la búsqueda de las innovaciones musicales ocasionadas por el cine mudo debe enfocarse hacia las improvisaciones y hacia las partituras hechas por mexicanos para películas extranjeras. Por desgracia, las improvisaciones por su misma índole no sobrevivieron, peto tal vez existen memorias de compositores y músicos que nos hablen sobre su trabajo en los cines, o tal vez todavía vivan quienes supriman la vergüenza de su pasado cinematográfico para que nos hablen libremente de sus experiencias. $\mathrm{Ni}$ duda cabe que hubo compositores que escribieron partituras adecuadas a determinadas películas, recordamos a Romualdo de Parma y a los que musicalizaron las películas de temas histórico-italiano. Carlos Chávez, el notable compositor mexicano fue pianista y organista del cine Olimpia, donde destacó por sus interpretaciones y, cosa sobresaliente, sus primeras composiciones de música culta nacionalista las dio a conocer en 1926. ¿En qué medida su experiencia cinematográfica le ayudó en sus innovaciones? ¿El universalismo de su nacionalismo radicará en el hecho de haber acompañado musicalmente películas, ya con improvisaciones o adecuando diversos tipos de melodías?

¿Quién es el iniciador de la música cinematográfica en la etapa sonora? ¿Max Urban o Silvestre Revueltas?

Max Urban demuestra en La mujer del puerto (1933) de Arcady 
Boytler que de algo le sirvió musicalizar 12 películas con anterioridad; ${ }^{68}$ hace gala de una maestría en el oficio. Difiere de la manera en que Miguel Lerdo de Tejada musicalizó Santa. Los títulos de la película son realzados con el tema musical en arreglo sinfónico. A partir de las primeras escenas la música se convierte en un elemento más del drama, no hay gratuidad en su empleo, por el contrario, siempre tiene la intención de subrayar la tragedia. A veces son tonos sinfónicos, un tanto operísticos, grandilocuentes, como cuando el doctor termina la auscultación del padre de la protagonista; sin mediar diálogo de por medio, el espectador se entera, mediante la actuación y la música, que son pocas las esperanzas de vida, aquélla sirve para transmitir el presentimiento del desenlace; unas cuantas frases subrayan lo intuido por el espectador. La música está conscientemente utilizada y cumple una función dramática en el relato, por tal motivo las canciones se integran perfectamente a la narración musical y a la cinematográfica. Una tonadilla, entre alegre y burlona, cantada por los marineros comunica su necesidad de mujeres después de un tiempo largo en alta mar; tampoco hay gratuidad en el número de variedades inserto en la película; sólo se muestra el final de un bailable español en el prostíbulo con el que nos enteramos de la euforia de los marinos; un danzón, auxiliado por la fotografía y la actuación, es el fondo musical más apropiado para sugerir el contacto sexual en el encuentro de los marinos con las prostitutas en el cabaret. De pronto surge el tema melódico tocado a gran orquesta y volumen; la escena es una calle con faroles por la que pasea Andrea Palma, se detiene en un poste eléctrico fumando un cigarrrillo mientras se escucha la letra de la canción-tema Vendo placer de Manuel Esperón. Otro danzón acompaña el encuentro de la heroína con Fernando Soler; la secuencia de la escaleria es de una sensualidad y un erotismo desbordantes. En fin que Max Urban demuestra un dominio total en su oficio. ¿Cuál es la diferencia entre su música y la de Silvestre Revueltas? ¿O la manera de

68 Sobre las olas (1932) de Miguel Zacarías, El espectador impertinente (1932) de Raphael J. Sevilla, La Llorona (1933) de Fernando de Fuentes, Juárez y Maximiliano (1933) de Miguel Contreras Torres, La noche del pecado (1933) de Miguel Contreras Torres, Sagrario (1933) de Ramón Peón, Profanación (1933) de Chano Urueta, El tigre de Yautepec (1933) de Fernando de Fuentes, El héroe de Nacozari (1933) de Guillermo Calles, Tiburón (1933) de Ramón Peón, Aguilas de América (1933) de Manuel $\mathrm{R}$. Ojeda, El vuelo de la muerte (1933) de Guillermo Calles, La mujer del puerto (1933) de Arcady Boytler y La sangre manda (1933) de José Bohor y Raphael J Sevilla. 
musicalizar películas de uno y otro compositor? ¿Por qué la música de Max Urban es audible solamente acompañada por imágenes cinematográficas y por qué la de Revueltas es audible por sí misma? ¿Compondría éste su música en función de sí misma más que en función del relato cinematográfico? ¿ $\mathrm{O}$, por el contrario, acentuó la influencia cinematográfica en su música y precisamente ahí está el secreto de sus innovaciones? Destaca que Chávez y Revueltas trabajaron para el cine. Una investigación acuciosa puede ser fuente de gratas sorpresas. 